\title{
Analysis of a DC-DC Flyback Converter Variant for Thermoelectric Generators with Partial Energy Processing
}

\author{
Ricardo Marroquín-Arreola ${ }^{1}\left(\mathbb{D}\right.$, Daniel Salazar-Pérez ${ }^{2}$, Mario Ponce-Silva ${ }^{2, *} \mathbb{1}$, Héctor Hernández-De León ${ }^{1, *}$, \\ Juan A. Aquí-Tapia ${ }^{3}$, Jinmi Lezama ${ }^{4}$ (), Yesica I. Saavedra-Benítez ${ }^{2}$, Elías N. Escobar-Gómez ${ }^{1}$, \\ Ricardo E. Lozoya-Ponce ${ }^{5}$ and Rafael Mota-Grajales ${ }^{1}$
}

check for

updates

Citation: Marroquín-Arreola, R.; Salazar-Pérez, D.; Ponce-Silva, M.; Hernández-De León, H.;

Aquí-Tapia, J.A.; Lezama, J.; Saavedra-Benítez, Y.I.; EscobarGómez, E.N.; Lozoya-Ponce, R.E.; Mota-Grajales, R. Analysis of a DC-DC Flyback Converter Variant for Thermoelectric Generators with Partial Energy Processing. Electronics 2021, 10, 619. https://doi.org/ 10.3390/electronics10050619

Academic Editor: Diego

Gonzalez Lamar

Received: 11 February 2021

Accepted: 4 March 2021

Published: 7 March 2021

Publisher's Note: MDPI stays neutral with regard to jurisdictional claims in published maps and institutional affiliations.

Copyright: (c) 2021 by the authors. Licensee MDPI, Basel, Switzerland. This article is an open access article distributed under the terms and conditions of the Creative Commons Attribution (CC BY) license (https:// creativecommons.org/licenses/by/ $4.0 /)$.
1 Tecnológico Nacional de México-I. T. de Tuxtla Gutiérrez, Tuxtla Gutiérrez, Chiapas 29050, Mexico D18270122@tuxtla.tecnm.mx (R.M.-A.); enescobarg@tuxtla.tecnm.mx (E.N.E.-G.); rafael.mg@tuxtla.tecnm.mx (R.M.-G.)

2 Tecnológico Nacional de México-CENIDET, Cuernavaca, Morelos 62490, Mexico; daniel.salazar@cenidet.edu.mx (D.S.-P.); yesica.sb@cenidet.tecnm.mx (Y.I.S.-B.)

3 Osram, Apodaca, Monterrey, Nuevo León 66626, Mexico; j.aqui@osram.com

4 Grupo de Circuitos y Sistemas Electrónicos de Alta Frecuencia, Universidad Nacional Tecnológica de Lima Sur, Lima 15834, Peru; jinmilezama@gmail.com

5 Tecnológico Nacional de México-I.T., Chihuahua 31200, Mexico; ricardo.lp@chihuahua.tecnm.mx

* Correspondence: mario.ps@cenidet.tecnm.mx (M.P.-S.); hector.hl@tuxtla.tecnm.mx (H.H.-D.L.)

\begin{abstract}
This paper presents a theoretical analysis of a DC-DC flyback converter variant applied in energy harvesting based on thermoelectric generators. The main contribution of the article is the analysis and obtaining the equations of the behavior of the converter with a rearrangement of the elements of the traditional flyback converter in such a way that the converter only processes part of the energy while the other part is delivered directly to the load. This is achieved by connecting the secondary of the flyback in series with the load, and this assembly, in turn, is placed in parallel with the primary and the voltage source. This configuration means that the topology can only be a boost topology; however, there are benefits such as partial power processing $\left(\mathrm{R}^{2} \mathrm{P}^{2}\right)$ and reduced stress on converter components in both voltage and current; all this leads to increase the efficiency. A Low Frequency Averaging Analysis (LFAA) was used to determine the behavior of the proposed circuit, and a simple equivalent circuit to analyze was obtained. In order to validate the theoretical analysis, a circuit was simulated in Spice and implemented in an $18 \mathrm{~W}$ prototype. Experimental results showed that the converter has an efficiency of $92.65 \%$. Moreover, the rearranged flyback processed only $56 \%$ of the input power.
\end{abstract}

Keywords: DC-DC flyback converter; partial energy processing; $\mathrm{R}^{2} \mathrm{P}^{2}$; thermoelectric generators

\section{Introduction}

In recent years, due to their application in eco-friendly energy collection systems, thermoelectric generators (TEG) have been studied [1]. TEGs do not generate acoustic noise, require little maintenance, and have a lifespan of 20 years, due to the lack of moving parts [2].

A TEG is a device that works with the principle of the Seebeck effect, which indicates that a voltage is created when two different conductors or semiconductors have a different temperature between them [3].

Some uses of TEGs in aerospace applications were reported [4]: automotive systems [5,6], eco-friendly stoves [7], battery charging [8], industrial processes [9], portable thermoelectric generators for power supply of ultra-low-power sensors [10], and sensing devices in remote pipelines [11].

There are different works related to DC-DC converters applied to thermoelectric generators for increasing the efficiency of these collection systems [12-15], in which the system 
is provided with maximum power point tracking control (MPPT) achieving efficiencies above $90 \%$ only by adjusting the working cycle. There are different papers in which flyback converters are proposed and used [16-18], either with extra components that modify their operation or jobs in which combinations of flyback and boost converters are used for different applications, including jobs with solar panels [19-22]. However, although it has promising results, flyback converters have been little used in applications related to energy collection systems using thermoelectric generators.

In [23-27], converter variations are shown where an adjustment is made in the operation of the circuit to change the energy processing in such a way that it is not processed completely, since they follow the principle of reduced redundant energy processing $\left(\mathrm{R}^{2} \mathrm{P}^{2}\right)$. Part of the energy is adapted to the output, and the other part goes directly to the load.

In [28], a circuit is shown where the components of the flyback converter are rearranged to make a power supply for LED applications that reduces voltage. Following this same idea, the modification proposed in this article consists of making a boost converter following the same principle of rearrangement of the flyback converter. This is done by connecting the secondary winding in series with the load and in turn placing it in parallel with the primary winding and the voltage source, in this case a TEG.

In this way, the galvanic isolation is eliminated and makes the source deliver a part of the energy directly to the load and the missing part is delivered by the converter. This configuration brings benefits such as increasing the efficiency of the entire system, reducing the voltage and current and voltage in each component. For the analysis of the converter, an averaged analysis was carried out, which resulted in an equivalent circuit being very easy to evaluate and thus determine its behavior and design method.

Similar articles have been found such as [29] which reports a fairly similar circuit; however, it does not make a rigorous analysis of the behavior of the converter, and to differentiate this article, an analysis of the circuit is made in two stages. The first analysis is when the converter is used for general purpose applications where the internal resistance of the source is too small to be neglected and the second analysis is when the converter is used for energy harvesting systems based on thermoelectric generators where the internal resistance of the source consumes a considerable part of the power ( $26 \%$ approximately) and reaches its maximum power transfer when the load is equal to the internal resistance of the source.

This paper is organized as follows: Section 2 presents and explains the operation and mathematical analysis of the converter in two cases, first when there is no internal resistance in the source and second when there is internal resistance in it. Section 3 focuses on converter design and simulation in Spice. Section 4 shows the results obtained, and finally, in Section 5, the main conclusions of this document are presented.

\section{Analysis of the Flyback Converter}

\subsection{Without Internal Resistance in the Source}

The difference between the basic flyback converter and the topology proposed is shown in Figure 1. This DC-DC converter consists of a variation of the flyback converter in which the primary winding is placed in series with the secondary winding and the load, thus eliminating galvanic insulation. This configuration makes the topology only boost topology; however, it gains benefits such as partial power processing, as the input voltage source directly delivers some of the power to the load, and the other part is handled by the flyback converter; this improves the overall efficiency of the system. 


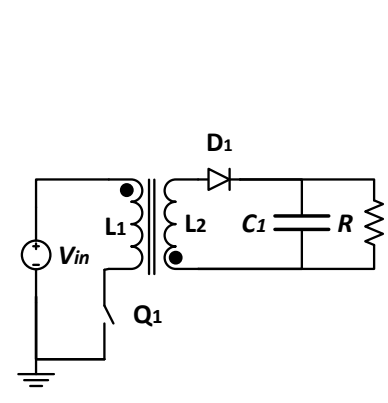

(a)

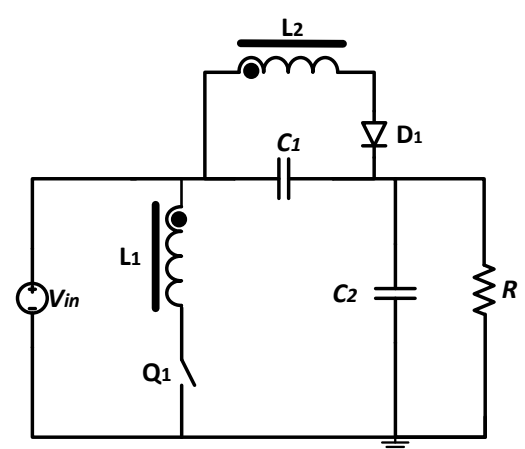

(b)

Figure 1. (a) Basic flyback and (b) modified flyback with partial energy processing.

Another advantage that is presented is that the voltage and current stresses in the converter are considerably reduced depending on the gain, due to the secondary having an output voltage equal to the difference between the output voltage and the input voltage and only providing the missing part.

In order to carry out the analysis of the rearranged flyback converter, an average analysis was used. The main idea is to assessment if the topology complies with the corresponding regulations, knowing its efficiency and evaluating its feasibility of implementation.

For this kind of analysis, it is needed to have some considerations like: the primary side can be represented as a loss-free resistance $\left(R_{f}\right)$, this resistance represents the average power delivered to the primary side of the flyback converter $\left(P_{f i}\right)$, and the energy "consumed" by this resistance is transferred to the secondary side of the flyback converter that is modeled as a direct current voltage source $\left(V_{f_{0}}\right)$, as shown in Figure 2.

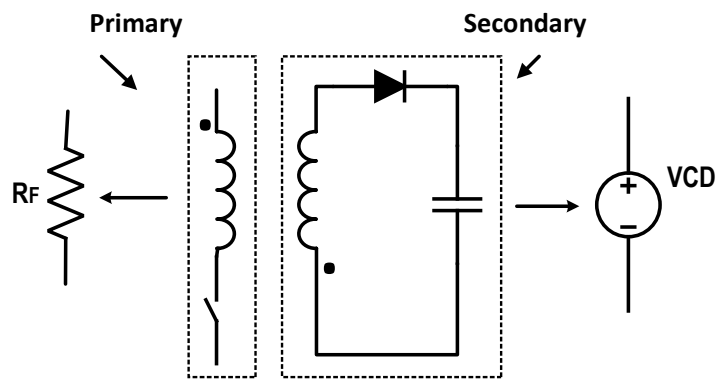

Figure 2. Flyback model in DCM for the low frequency averaging analysis (LFAA).

Applying the last considerations in the circuit of Figure 1b, an equivalent circuit was obtained which is shown in Figure 3. Where $V_{\text {in }}$ is the input Voltage, $I_{\text {in }}$ is the input Current, $V_{f_{0}}$ is the average output voltage in the secondary side of the flyback converter, $I_{R f}$ is the average input current in the primary side of the flyback converter, $R_{f}$ loss-free resistance representing the primary side of the Flyback converter, $V_{o}$ represents the output voltage of the load, $I_{0}$ is the output current. This equivalent circuit is easier to evaluate than a conventional analysis in high frequency.

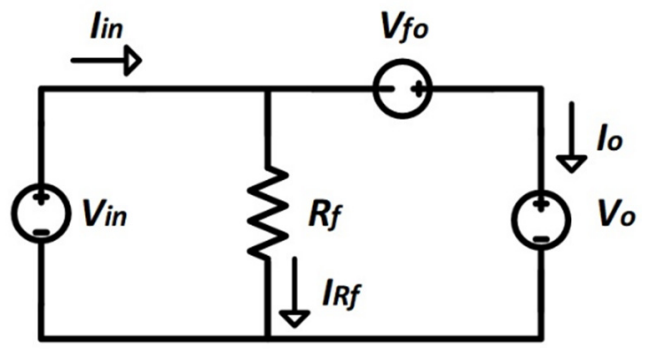

Figure 3. Equivalent circuit in low frequency averaged analysis. 
In the second mesh, it can define the averaged current flowing by the resistance of the primary $\left(I_{R f}\right)$, and by adding currents in the upper node the input current $\left(I_{\text {in }}\right)$, it was calculated.

$$
\begin{gathered}
I_{R f}=\frac{V_{o}-V_{f o}}{R_{f}}=\frac{V_{i n}}{R_{f}} \\
I_{i n}=I_{o}+I_{R f}=I_{o}+\frac{V_{i n}}{R_{f}}
\end{gathered}
$$

The average output power $\left(P_{f_{0}}\right)$ and average input power $\left(P_{f_{i}}\right)$ of the flyback converter can be related considering the efficiency of the converter $\left(\eta_{f}\right)$, as shown in (3).

$$
P_{f o}=\eta_{f} P_{f i}
$$

where $P_{f_{0}}$ and $P_{f i}$ can be defined as

$$
\begin{gathered}
P_{f_{o}}=V_{f o} I_{o} \\
P_{f i}=I_{R f}^{2} R_{f}
\end{gathered}
$$

Replacing (5) y (4) in (3) $R_{f}$, the following was obtained:

$$
R_{f}=\frac{V_{f_{o}} I_{o}}{\eta_{f} I_{R f}^{2}}=\frac{\left(V_{o}-V_{i n}\right) I_{o}}{\eta_{f} I_{R f}^{2}}
$$

Finally, (2) is replaced in (7) clearing the resistance value of the primary flyback $\left(R_{f}\right)$, as shown in (7).

$$
R_{f}=\frac{\eta_{f}\left(V_{o}-V_{f o}\right)^{2}}{V_{f_{o}} I_{o}}=\frac{\eta_{f} V_{i n}{ }^{2}}{\left(V_{o}-V_{i n}\right) I_{o}}
$$

With the equations defined for $R_{f}$ and $V_{f_{0}}$, it is possible to determine the power that the flyback converter will process. The part of energy processed by the converter with respect to the total power is called $Q$, which is defined in (8).

$$
\begin{gathered}
Q=\frac{P_{f i}}{P_{i n}}=\frac{\frac{P_{f o}}{\eta_{f}}}{\left(P_{o}-P_{f o}\right)+P_{f i}}=\frac{1}{\eta_{f}} \frac{1}{\frac{P_{o}-P_{f o}+P_{f i}}{P_{f o}}} \\
Q=\frac{1}{1+\frac{\eta_{f}}{M-1}}
\end{gathered}
$$

where $M$ is the gain defined as $V_{o} / V_{i n}$.

The power flow diagram of a conventional flyback compared with the rearranged flyback are shown in Figure 4, where $P_{\text {in }}$ is the input power, $P_{o}$ is the output power.

(a)

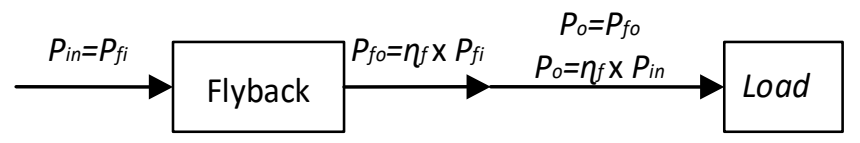

(b) $P$

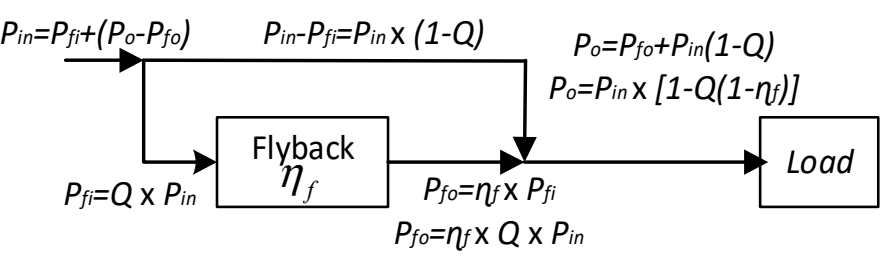

Figure 4. Power flow diagrams of the conventional flyback converter (a) and the proposed circuit (b). 
In this diagram, it is easier to understand the operation of the proposed converter, in which it is observed as part of the input power $P_{\text {in }}$ supplied directly to the load, while the other fraction is processed by the flyback converter. Therefore, the total efficiency with respect to the conventional flyback will be improved.

The range of $Q$ must be $0<Q<1$; if $Q$ is greater than 1 , there is no point in implementing the topology since instead of having benefits, low efficiency and greater electrical size would be obtained concerning an isolated basic flyback.

The total efficiency is calculated according to (9).

$$
\begin{gathered}
\eta_{T}=\frac{P_{o}}{P_{i n}}=\frac{P_{o}}{\left(P_{o}-P_{f o}\right)+P_{f i}}=\frac{1}{1+\frac{P_{f i}}{P_{o}}-\frac{P_{f o}}{P_{o}}} \\
\eta_{T}=\frac{M \eta_{f}}{M+\eta_{f}-1}
\end{gathered}
$$

To better observe the behavior of Equations (8) and (9), both were plotted for the efficiency values of the flyback converter of $0.9,0.7$, and 0.5 , and the results are shown in Figures 5 and 6.

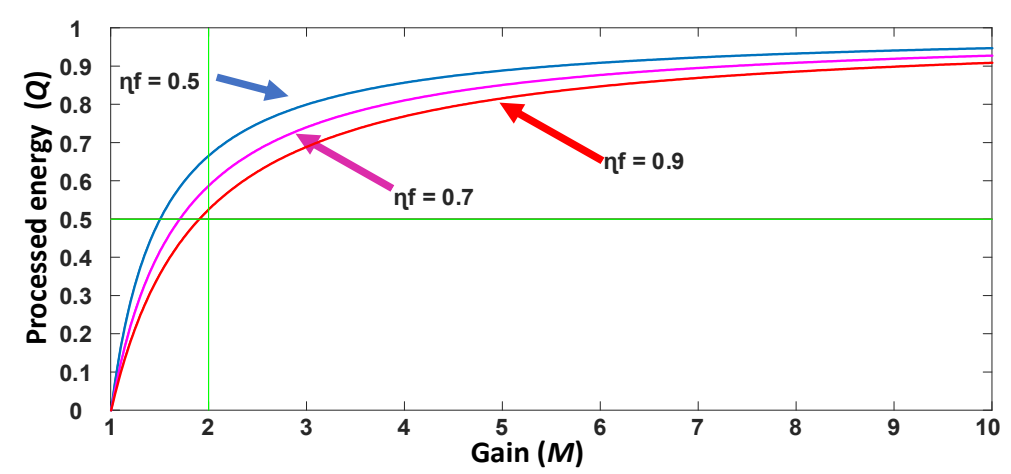

Figure 5. Behavior of processed energy with respect to gain.

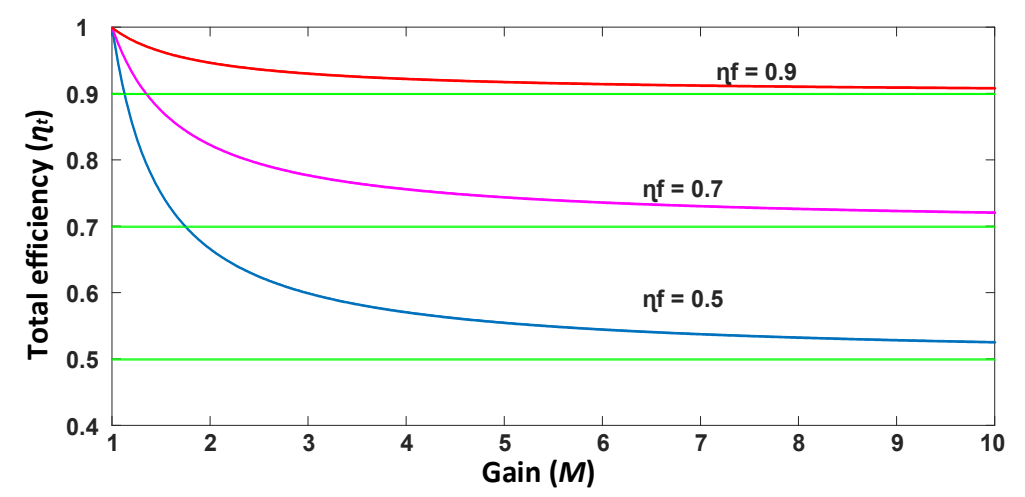

Figure 6. Total efficiency behavior with respect to gain.

Figure 5 provides a graph of the behavior of processed energy $Q$ with respect to gain $M$. It is inferred that the proposed converter will process less energy when the gain is small and the efficiency of the converter is higher.

Figure 6 provides a graph of the behavior of total efficiency $\eta_{t}$ with respect to gain $M$. It is observed that, for very high gains, the efficiency of the flyback converter and the total efficiency tend to be equal. However, for small gains, it is observed that the total efficiency is considerably improved concerning flyback efficiency. 


\subsection{With Internal Resistance in the Source}

When using energy harvesting systems with low efficiency like TEGs, it is necessary to consider the internal resistance due to it is too large with respect to the power they can supply. The value of the internal resistance ranges from $0.9 \mathrm{Ohms}$ to $1.43 \mathrm{Ohms}$ for each TEG depending of the material. For this reason, it is necessary to consider the internal resistance of the TEG's in the proposed converter model. The internal resistance $\left(R_{S}\right)$ is represented as a resistance in series with the voltage source.

The converter circuit matched with the new resistance $R_{s}$ is shown in Figure 7. This change also brings about changes in the equivalent simplified circuit and in the energy flow diagram, which are shown in Figures 8 and 9, respectively.

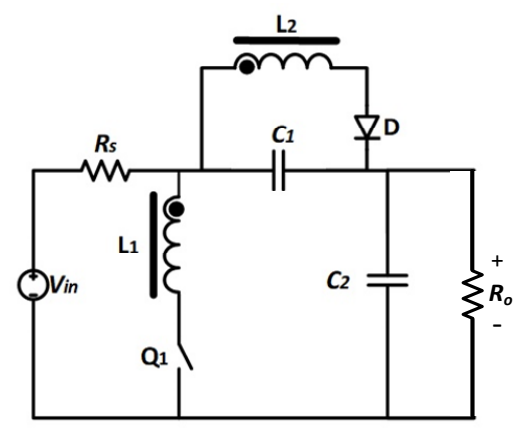

Figure 7. Modified flyback converter for thermoelectric generators.

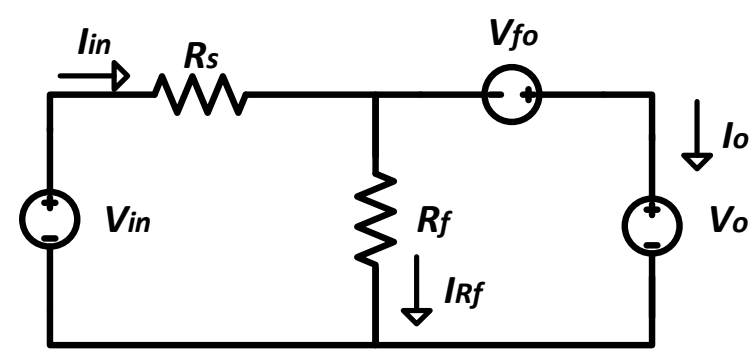

Figure 8. Equivalent circuit in low frequency averaged analysis.

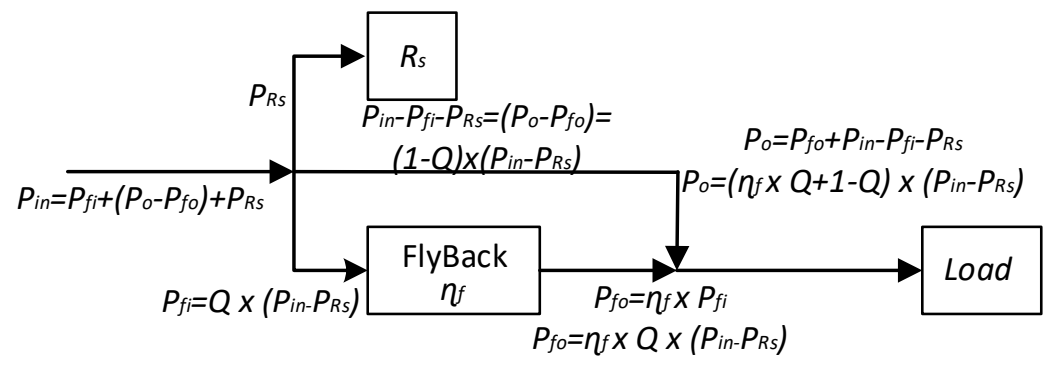

Figure 9. Power flowchart.

With the new considerations of the TEG as a source in the equivalent circuit shown in Figure 8 , some of the equations of the averaged model will also change. The equations of the input current $\left(I_{i n}\right)$ and current of the flyback resistance $\left(I_{R f}\right)$ can no longer be a function of the input voltage $\left(V_{i n}\right)$, so the output voltages $V_{o}$ and $V_{f_{0}}$ are used to define them.

$$
\begin{gathered}
I_{R f}=\frac{V_{o}-V_{f o}}{R_{f}} \\
I_{\text {in }}=I_{o}+I_{R f}=I_{o}+\frac{V_{o}-V_{f o}}{R_{f}}
\end{gathered}
$$


For the power ratios that correspond to the flyback converter, they will remain the same as in the previous case. The average input power $\left(P_{f_{i}}\right)$, the average output power $\left(P_{f_{0}}\right)$, and the efficiency of the flyback converter $\left(\eta_{f}\right)$ were shown in (5), (4), and (3), respectively. of $R_{f}$.

By substituting (4), (5), and (10) in (3), an expression is obtained to calculate the value

$$
R_{f}=\frac{\eta_{f}\left(V_{o}-V_{f_{o}}\right)^{2}}{V_{f_{o}} I_{o}}
$$

Using the outer network in the equivalent circuit in Figure 8, an expression can be obtained to calculate the value of $V_{\text {in }}$.

$$
V_{\text {in }}=R_{s} I_{\text {in }}+V_{o}-V_{f o}
$$

Substituting (12) in (11) and (11) in (13), a quadratic equation was obtained to determine $V_{f o}$ as a function of known variables, as shown in (14).

$$
\begin{gathered}
V_{i n}+V_{f o}=R_{S}\left(I_{o}+\frac{V_{o}-V_{f o}}{\frac{\eta_{f}\left(V_{o}-V_{f o}\right)^{2}}{V_{f o} I_{o}}}\right)+V_{o} \\
V_{f o}^{2}+\left(V_{i n}-2 V_{o}+R_{s} I_{o}\left(\frac{1-\eta_{f}}{\eta_{f}}\right)\right) V_{f o}-\left(V_{i n}-V_{o}-R_{s} I_{o}\right) V_{o}=0 \\
V_{f o}=V_{o}-R_{s} I_{o}\left(\frac{1-\eta_{f}}{2 \eta_{f}}\right)-\frac{V_{i n}}{2} \pm \sqrt{\left(\frac{V_{i n}}{2}+R_{s} I_{o}\left(\frac{1-\eta_{f}}{2 \eta_{f}}\right)\right)^{2}-\frac{R_{s} I_{o} V_{o}}{\eta_{f}}}
\end{gathered}
$$

With (12) and (14), the values to have $R_{f}$ and $V_{f_{0}}$ are calculated in the equivalent circuit shown in Figure 8. The expression is also calculated to determine the energy processed by the Flyback converter with respect to the total power $(Q)$ using the power flowchart shown in Figure 9.

$$
Q=\frac{P_{f i}}{P_{\text {in }}-P_{R s}}=\frac{1}{1+\eta_{f}\left(\frac{V_{o}}{V_{f_{o}}}-1\right)}
$$

Using the same power flow scheme, the total efficiency of the circuit is calculated considering the internal resistance $R_{S}$ of the thermoelectric generator.

$$
\eta_{T}=\frac{P_{o}}{P_{\text {in }}-P_{R s}}=\frac{1}{1+\frac{V_{f o}}{V_{o}}\left(\frac{1}{\eta_{f}}-1\right)}
$$

With the variables already determined of $V_{R f}, V_{f o}$, and $P_{f i}$, it is possible to calculate the elements of the flyback converter with the conventional equations for the discontinuous conduction mode. Since the conventional flyback converter is a circuit that has already been widely studied in the literature, no emphasis will be placed on the equations for calculating the components.

The gain of the flyback converter $\left(M_{f}\right)$ is defined as:

$$
M_{f}=\frac{V_{f o}}{V_{f i n}}
$$

If a duty cycle $(D)$ and a discharge cycle (Desc) are proposed to ensure discontinuity, the ratio of turns $(n)$ can be solved from the conventional flyback converter gain equation as shown in (18).

$$
n=\frac{D}{M_{f} \cdot \operatorname{Desc}}
$$


In order to calculate the inductance of the primary $\left(L_{1}\right)$, the power that it must handle for each switching is considered, and (19) is obtained, and in turn, it is reflected with the ratio of turns $n$ to obtain the inductance of the secondary $\left(L_{2}\right)$.

$$
\begin{gathered}
L_{1}=\frac{V_{R f}^{2} D^{2}}{2 f_{s} P_{f i}} \\
L_{2}=\frac{L_{1}}{n^{2}}
\end{gathered}
$$

Finally, the capacitors will be calculated with respect to the voltage, power, and frequency at which they are working as shown in (21) and (22).

$$
\begin{aligned}
& C_{1}=\frac{P_{f 0}}{4 \pi f_{s} V_{f_{o}}^{2} \Delta V} \\
& C_{2}=\frac{P_{o}}{4 \pi f_{s} V_{o}^{2} \Delta V}
\end{aligned}
$$

\section{Design of the Rearranged Flyback Converter}

This section shows the components selected for the implementation of the rearranged flyback.

In order to corroborate the behavior of the proposed converter, it was decided to work with TEGs manufactured by "Custom Thermoelectric" with Model: 1261G-7L31-10CX1. Each TEG used has an open-circuit voltage $\left(V_{o c}\right)$ of $5.325 \mathrm{~V}$ when subjected to a hot side temperature of $200{ }^{\circ} \mathrm{C}$ and $50{ }^{\circ} \mathrm{C}$ on the cold side. The internal resistance of each TEG at that temperature is $1.1 \Omega$.

For this experiment, 4 TEGs connected in series were used. Therefore, the input is defined as a voltage source of $21.3 \mathrm{~V}\left(V_{i n}\right)$ and total internal resistance in series of $4.4 \Omega$ $\left(R_{S}\right)$. For the load, a resistive load of $48.22 \Omega\left(R_{o}\right)$ of $19.29 \mathrm{~W}\left(P_{o}\right)$ was selected, supplied with a voltage of $30.5 \mathrm{~V}\left(V_{o}\right)$.

In order to calculate the components of the converter, some design parameters must be proposed, which are shown in Table 1, among them, it should be noted that the discharge cycle ensures the discontinuity of the converter.

Table 1. Specifications.

\begin{tabular}{ccc}
\hline Symbol & Quantity & Value \\
\hline$R_{s}$ & Total internal resistance of TEG's & $4.4 \Omega$ \\
Desc & Discharge cycle & 0.25 \\
$V_{i n}$ & Open circuit voltage of TEG's & $21.3 \mathrm{~V}$ \\
$P_{o}$ & Output power & $19.29 \mathrm{~W}$ \\
$V_{o}$ & Output voltage & $30.5 \mathrm{~V}$ \\
$R_{o}$ & Load resistance & $48.22 \Omega$ \\
$f_{s}$ & Switching frequency & $100 \mathrm{kHz}$ \\
$D$ & Duty cycle & 0.75 \\
$\eta_{f}$ & Proposed efficiency of the converter & $90 \%$ \\
\hline
\end{tabular}

Table 2 shows the values obtained from the equations of the proposed model with the values of Table 1 , where $P_{R s}$ is the power consumed by the total internal resistance of TEGs, $P_{i n}$ is the input power provided by the TEG's without considering $P_{R s}$. 
Table 2. Data obtained from model equations.

\begin{tabular}{ccc}
\hline Symbol & Quantity & Value \\
\hline$I_{0}$ & Output current & $0.6325 \mathrm{~A}$ \\
$P_{\text {in }}$ & TEG's input power & $27.88 \mathrm{~W}$ \\
$P_{R s}$ & Power consumed in Rs & $7.537 \mathrm{~W}$ \\
$I_{i n}$ & TEG's input current & $1.390 \mathrm{~A}$ \\
$L_{1}$ & Primary inductor & $64.62 \mu \mathrm{H}$ \\
$L_{2}$ & Secondary inductor & $6.65 \mu \mathrm{H}$ \\
$R_{f}$ & Loss-free resistance of equivalent circuit in low frequency & $22.975 \Omega$ \\
$V_{f o}$ & Flyback output voltage on the equivalent circuit in low frequency & $14.959 \mathrm{~V}$ \\
$V_{R f}$ & Loss-free resistance voltage & $15.541 \mathrm{~V}$ \\
$I_{R f}$ & Loss-free resistance current & $0.676 \mathrm{~A}$ \\
$P_{f i}$ & Flyback input power & $10.512 \mathrm{~W}$ \\
$P_{f o}$ & Flyback output power & $9.461 \mathrm{~W}$ \\
$Q$ & Processed power in flyback & $51.67 \%$ \\
$M_{f}$ & Flyback converter gain & 0.9625 \\
$M$ & Converter gain & 1.4319 \\
$P_{o}-P_{f o}$ & Power delivered directly to the load & $9.93 \mathrm{~W}$ \\
\hline
\end{tabular}

Figure 10 shows the circuit simulated in Spice using the component values in Table 2. The Spice version used was OrCAD Lite v17.2-2016. Moreover, the three parts of the total circuit are also identified, which are TEGs consisting of $V_{i n}$ and Rs, modified flyback converter made up of $L_{1}, L_{2}$, the switch S1, diode D1, and capacitors $C_{1}$ and $C_{2}$. The third part is the load resistance, represented by $R_{o}$.

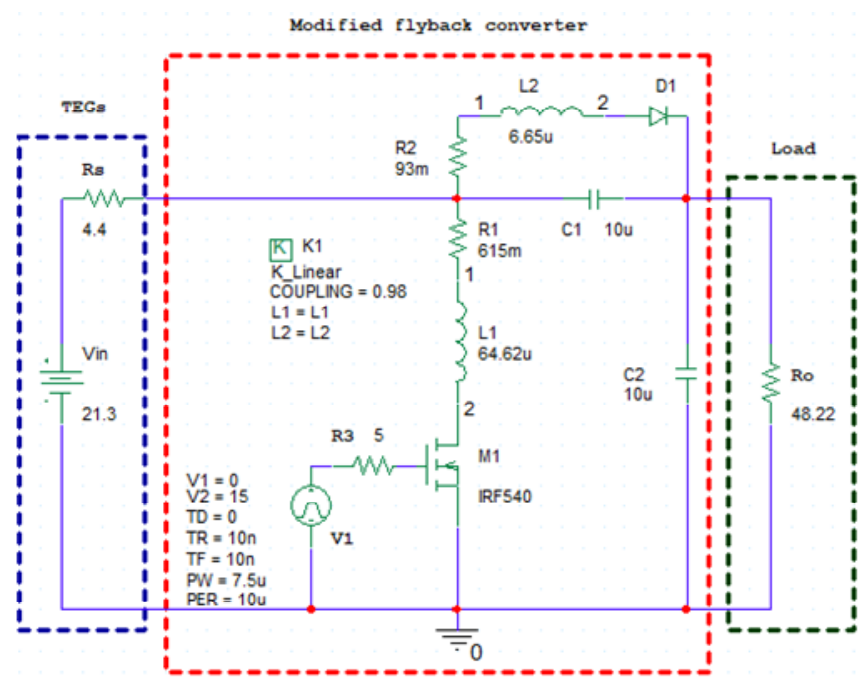

Figure 10. Simulation of the flyback converter in PSpice.

Figures 11-13 show the simulation results obtained in Spice. In the first figure, the waveforms of the input and output voltages $\left(v_{\text {in }}(t), v_{0}(t)\right)$, input and output currents $\left(i_{\text {in }}(t)\right.$, $\left.i_{o}(t)\right)$, and currents of the primary and secondary inductors $\left(i_{L 1}(t), i_{L 2}(t)\right)$ are observed. It can be seen that the flyback converter works in the conventional way and that it is working in discontinuous conduction mode. 


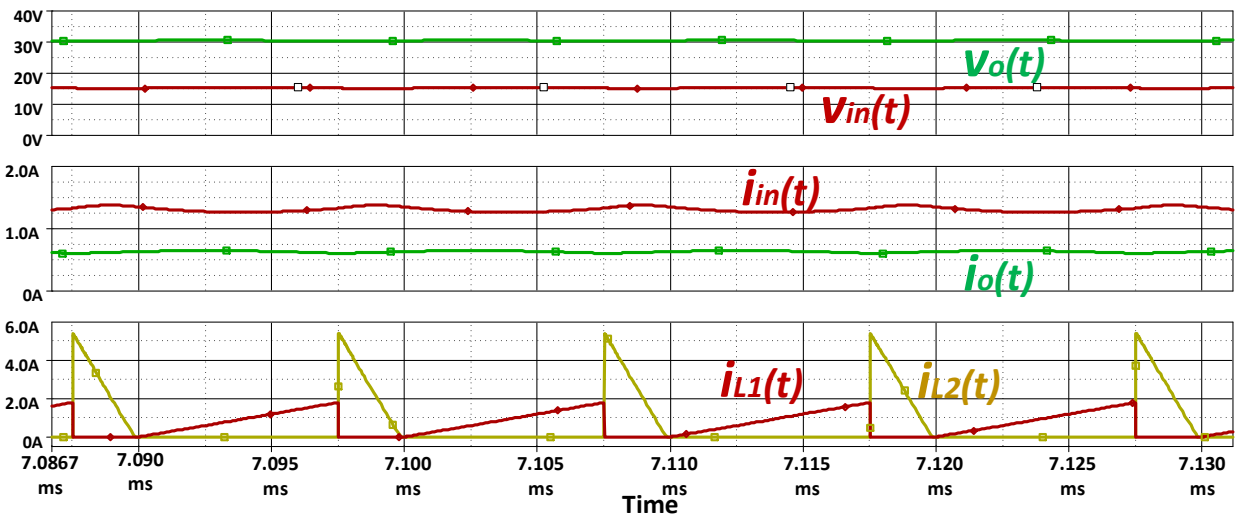

Figure 11. Simulation results. Input and output voltages $\left(v_{i n}(t), v_{0}(t)\right)$; input and output currents $\left(i_{\text {in }}(t), i_{o}(t)\right)$; currents of the primary and secondary inductors $\left(i_{L 1}(t), i_{L 2}(t)\right)$.

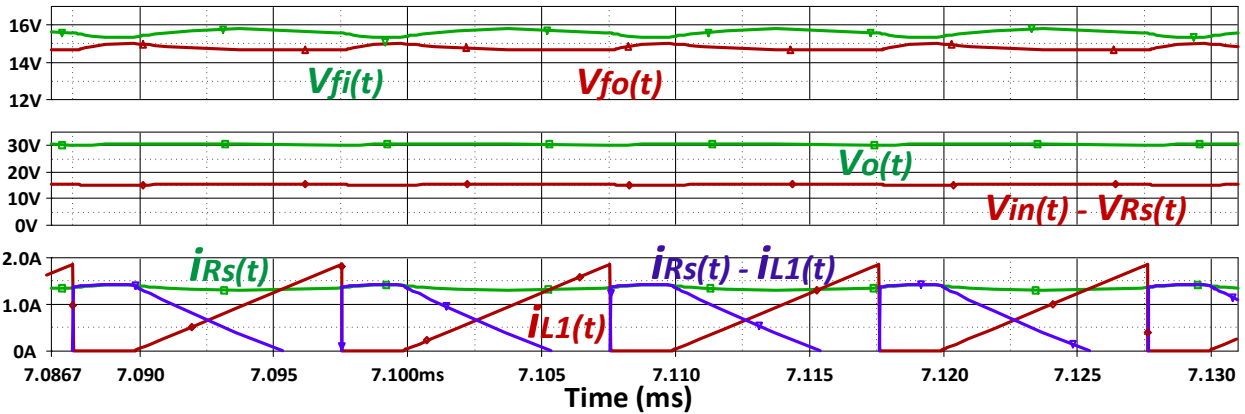

Figure 12. Simulation results. Input and output voltages of the flyback converter $\left(v_{f i n}(t), v_{f o}(t)\right)$; output voltage $\left(v_{0}(t)\right)$ and voltage of the TEGs $\left(v_{i n}(t)-v_{R s}(t)\right)$; input current $\left(i_{R s}(t)\right)$, current of the primary inductors $\left(i_{L 1}(t)\right)$, and current that is delivered directly to the load $\left(i_{R s}(t)-i_{L 1}(t)\right)$.

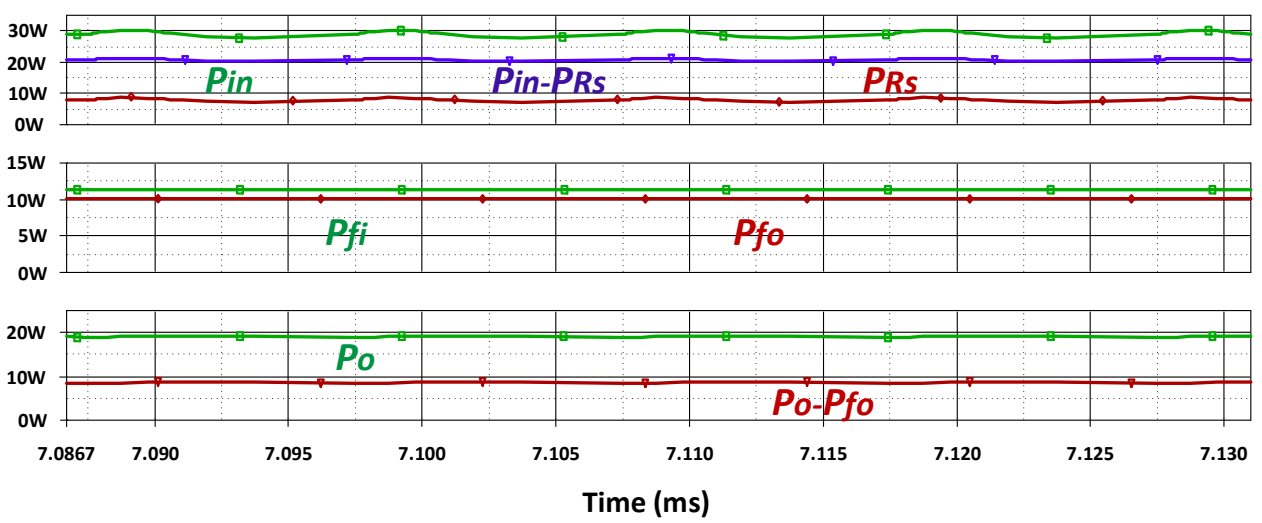

Figure 13. Simulation results. Input power $\left(P_{i n}\right)$, power consumed by $R_{S}\left(P_{R s}\right)$, and power delivered by the TEGs $\left(P_{i n}-P_{R s}\right)$; input and output power of the flyback converter $\left(P_{f i n}, P_{f o}\right)$; output power $\left(P_{o}\right)$ and power that is delivered directly to the load $\left(P_{o}-P_{f_{0}}\right)$.

Figure 12 shows the input and output voltages of the flyback converter $\left(v_{f i n}(t), v_{f_{o}}(t)\right)$, the output voltage $\left(v_{o}(t)\right)$ and voltage of the TEGs $\left(v_{i n}(t)-v_{R s}(t)\right)$, input current $\left(i_{R s}(t)\right)$, current of the primary inductors $\left(i_{L 1}(t)\right)$, and current that is delivered directly to the load $\left(i_{R s}(t)-i_{L 1}(t)\right)$. In this image, it is better observed how partial energy processing works and its benefits. The output voltage $\left(v_{0}(t)\right)$ is made up of the sum of the voltage of the TEGs $\left(v_{i n}(t)-v_{R s}(t)\right)$ and the output voltage of the flyback converter $v_{f_{o}}(t)$, each contributing around $15 \mathrm{~V}$. This makes the converter gain almost unity (0.9625). Finally, the third graph shows how the input current $\left.i_{R s}(t)\right)$ is not pulsating even though the current of the primary 
inductor $\left(i_{L 1}(t)\right)$ has the classic triangular shape; this is compensated since the current that flows directly to the load is pulsating and is complemented by the inductor current.

Figure 13 shows the average powers consumed or contributed by each element, the input power $\left(P_{i n}\right)$, power consumed by $R_{s}\left(P_{R s}\right)$, and power delivered by the TEGs $\left(P_{i n}-P_{R s}\right)$; input and output power of the flyback converter $\left(P_{f i n}, P_{f_{0}}\right)$; and output power $\left(P_{o}\right)$ and power that is delivered directly to the load $\left(P_{o}-P_{f_{0}}\right)$. In the first graph, the behavior of the TEGs model is observed, since in reality the power supplied by these would be $P_{i n}-P_{R s}$. In the second graph, the good efficiency in the flyback converter can be observed since it does not reduce its power much. And finally, the third graph shows the power that was not processed by the flyback converter and that is delivered directly to the load that corresponds almost ideally to the $9.83 \mathrm{~W}$ that were calculated.

\section{Experimental Results}

A laboratory prototype has been built to carry out experimental tests and evaluate the performance of the proposed converter. A MOSFET IRF540N model and a U1520 diode model were used. The prototype for experimental tests is shown in Figure 14.

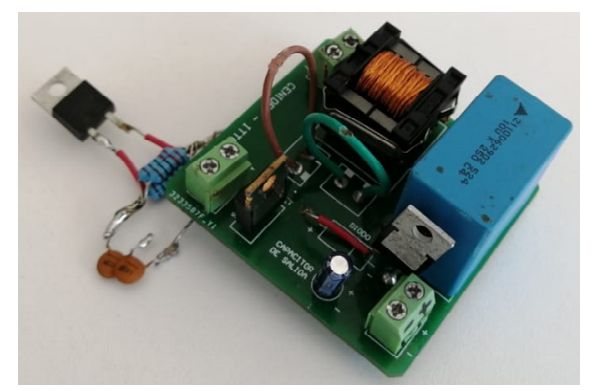

Figure 14. Prototype of the topology for experimental tests.

The values of the components used in the prototype are shown in Table 3. In addition, a snubber was used to suppress the harmonics and voltage spikes of the MOSFET, which is made up of a U1520 diode $\left(D_{\text {snubber }}\right)$, a ceramic capacitor $\left(C_{\text {snubber }}\right)$ of $5 \mathrm{nF}$, and a resistance $\left(R_{\text {snubber }}\right)$ of $55 \Omega$. The results of the simulation are presented and compared with Theoretical and experimental in Table 4.

Table 3. Components Used in Prototype.

\begin{tabular}{ccc}
\hline Symbol & Quantity & Value \\
\hline$R_{s}$ & Total internal resistance of TEGs & $4.4 \Omega$ \\
$L_{1}$ & Primary inductor & $72.995 \mu \mathrm{H}$ \\
$L_{2}$ & Secondary inductor & $5.932 \mu \mathrm{H}$ \\
& Core & $\mathrm{B} 66311$ \\
& Coil former & $\mathrm{EF} 20$ \\
& Number of threads in L1 & 10 \\
$n$ & Number of threads in L2 & 12 \\
$N_{p}$ & Transformation relation & 3.5 \\
$N_{s}$ & Number of turns of primary & 32 \\
& Number of turns of secondary & 9 \\
$C_{1}$ & Wire gauge & $33 \mathrm{awg}$ \\
$C_{2}$ & Input capacitor & $10 \mu \mathrm{F}$ \\
$R_{o}$ & Output capacitor & $10 \mu \mathrm{F}$ \\
$M_{1}$ & Load resistance & $51.8 \Omega$ \\
$D_{1}$ & MOSFET & $\mathrm{IRF} 540 \mathrm{~N}$ \\
$R_{\text {snubber }}$ & Diode & $\mathrm{U} 1520$ \\
$D_{\text {snubber }}$ & Snubber resistance & $55 \Omega$ \\
$C_{\text {snubber }}$ & Snubber Diode & $\mathrm{U} 1520$ \\
\hline
\end{tabular}


Table 4. Summary of results of the topology.

\begin{tabular}{cccc}
\hline Parameter & Ideal & PSpice & Prototype \\
\hline Input Voltage $V_{\text {in }}$ & $21.3 \mathrm{~V}$ & $21.3 \mathrm{~V}$ & $21.3 \mathrm{~V}$ \\
Internal resistance $R s$ & $4.4 \Omega$ & $4.4 \Omega$ & $4.4 \Omega$ \\
Input current $I_{i n}$ & $1.309 \mathrm{~A}$ & $1.3754 \mathrm{~A}$ & $1.272 \mathrm{~A}$ \\
Input power $P_{i n}$ & $27.88 \mathrm{~W}$ & $29.296 \mathrm{~W}$ & $27.09 \mathrm{~W}$ \\
Power consumed in $R_{s}$ & $7.537 \mathrm{~W}$ & $8.4514 \mathrm{~W}$ & $7.036 \mathrm{~W}$ \\
Primary inductor $L_{1}$ & $64.62 \mu \mathrm{H}$ & $64.62 \mu \mathrm{H}$ & $72.995 \mu \mathrm{H}$ \\
Secondary inductor $L_{2}$ & $6.65 \mu \mathrm{H}$ & $6.65 \mu \mathrm{H}$ & $5.932 \mu \mathrm{H}$ \\
Flyback input power $P_{f i}$ & $10.512 \mathrm{~W}$ & $11.945 \mathrm{~W}$ & $11.3 \mathrm{~W}$ \\
Flyback output power $P_{f o}$ & $9.461 \mathrm{~W}$ & $10.733 \mathrm{~W}$ & $10.08 \mathrm{~W}$ \\
Load $R_{o}$ & $48.22 \Omega$ & $48.22 \Omega$ & $51.8 \Omega$ \\
Output voltage $V_{o}$ & $30.5 \mathrm{~V}$ & $30.514 \mathrm{~V}$ & $30.71 \mathrm{~V}$ \\
Output current $I_{o}$ & $0.6325 \mathrm{~A}$ & $0.6328 \mathrm{~A}$ & $0.6053 \mathrm{~A}$ \\
Output power $P_{o}$ & $19.29 \mathrm{~W}$ & $19.31 \mathrm{~W}$ & $18.58 \mathrm{~W}$ \\
Processed power in flyback $Q$ & $51.67 \%$ & $57.3 \%$ & $56.34 \%$ \\
Flyback efficiency $\eta_{f}$ & $90 \%$ & $89.85 \%$ & $89.2 \%$ \\
Real system efficiency $\eta_{s}$ & $94.82 \%$ & $92.638 \%$ & $92.65 \%$ \\
\hline
\end{tabular}

In order to perform the characterization of the behavior of the proposed converter, tests were carried out with a voltage source and a variable resistance to emulate the behavior of the TEGs. This was done because it is difficult to keep the desired temperature constant in the TEGs.

Figure 15 shows the graph obtained from the input values, the input voltage $\left(V_{\text {in }}\right)$ is $21.3 \mathrm{~V}$ at $4.0 \mathrm{~V} / \mathrm{div}$, the input current $\left(I_{\text {in }}\right)$ is $1.272 \mathrm{~A}$ at $300 \mathrm{~mA} / \mathrm{div}$, the power supplied by the source $\left(P_{\text {in }}\right)$ is $27.09 \mathrm{~W}$ at $4.0 \mathrm{~W} / \mathrm{div}$, PWM voltage $\left(V_{\text {pulse }}\right)$ is $14.78 \mathrm{~V}$ at $10 \mathrm{~V} / \mathrm{div}$. In this figure, it can be seen how the input current is not pulsating, unlike a conventional flyback converter.

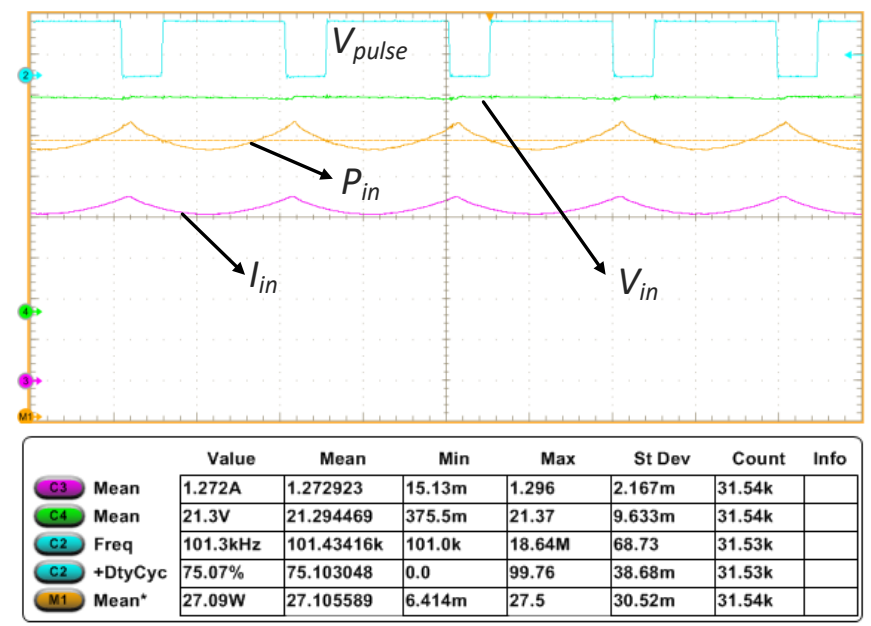

Figure 15. Input voltage and current graph.

In order to simulate the internal resistance of TEGs, a rheostat set to $4.4 \Omega$ was used. The voltage in the resistance $\left(V_{R s}\right)$ is $5.59 \mathrm{~V}$ at $1 \mathrm{~V} / \mathrm{div}$, the current through it $\left(I_{\text {in }}\right)$ is $1.256 \mathrm{~A}$ at $300 \mathrm{~mA} / \mathrm{div}$, and the power consumed $\left(P_{R s}\right)$ is $7.036 \mathrm{~W}$ at $2 \mathrm{~W} / \mathrm{div}$. As shown in Figure 16. 


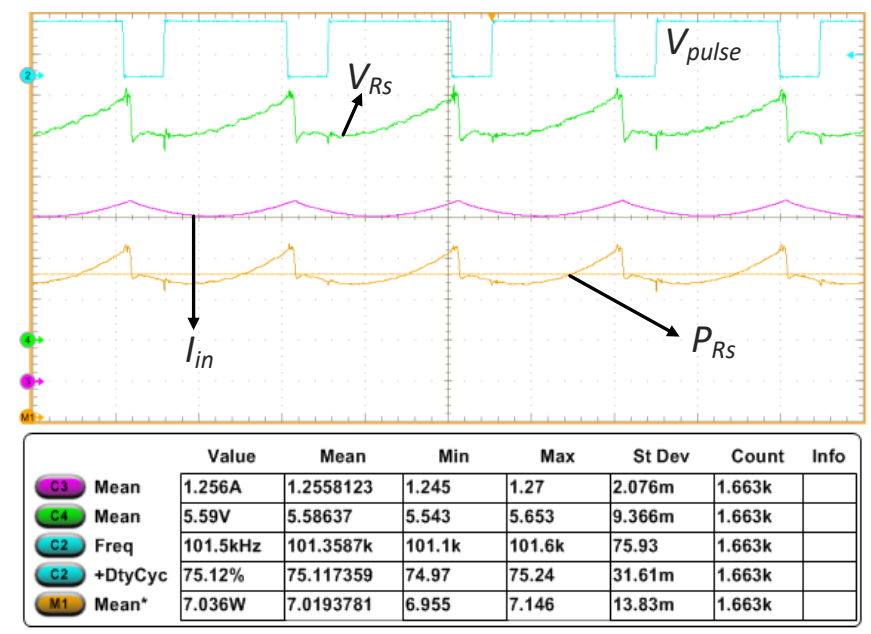

Figure 16. Internal resistance voltage graph.

Figure 17 shows the output voltage $\left(V_{o}\right)$ that is $30.71 \mathrm{~V}$ at $5 \mathrm{~V} / \mathrm{div}$, the current through the load $\left(I_{o}\right)$ is $605.3 \mathrm{~mA}$ at $300 \mathrm{~mA} / \mathrm{div}$, and the power consumed $\left(P_{o}\right)$ is $18.58 \mathrm{~W}$ at $4 \mathrm{~W} / \mathrm{div}$. In addition to that, a ripple of $0.61 \%$ was obtained in the output voltage and $0.82 \%$ in the case of the current.

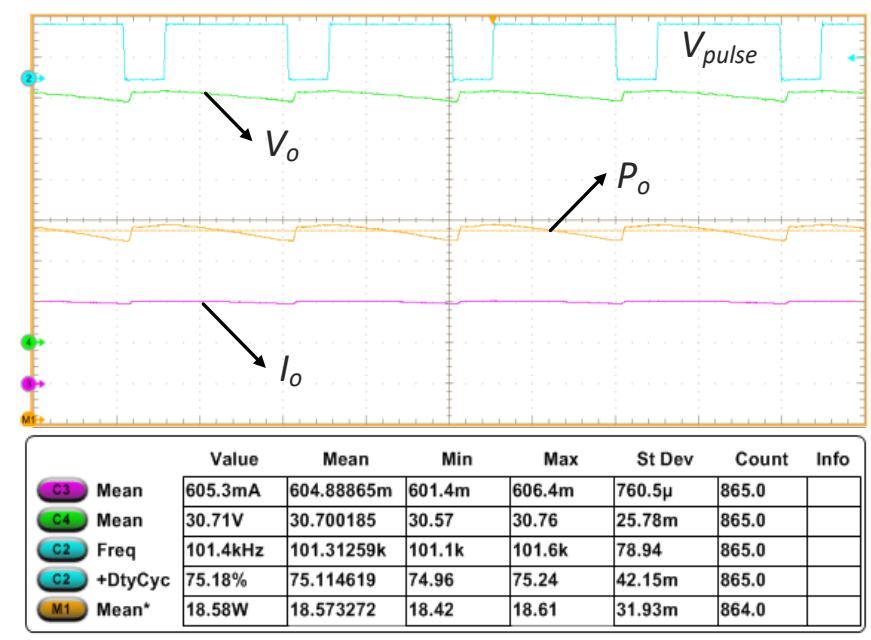

Figure 17. Output voltage and current graph.

The flyback input voltage in the flyback converter $\left(V_{f i}\right)$ is $16.37 \mathrm{~V}$ at $3 \mathrm{~V} / \mathrm{div}$, the average current through the primary side $\left(I_{L 1}\right)$ is $701.9 \mathrm{~mA}$ at $500 \mathrm{~mA} / \mathrm{div}$, the maximum peak current is $1.64 \mathrm{~A}$, and the average input power in the flyback converter $\left(P_{f i}\right)$ is $11.3 \mathrm{~W}$ at $10 \mathrm{~W} /$ div; this is seen in Figure 18.

Finally, Table 4 shows a comparative table of all the important variables for the calculations, simulation, and implementation. The slight variations that can be observed are due to implementation details such as the value of the inductances that are not exact or losses due to coupling. In a quantitative way, the percentage of error can be seen in Table 5 for each parameter. The largest errors were obtained in the inductances, since it is difficult to construct them when the calculation of the number of turns is not a whole number. 


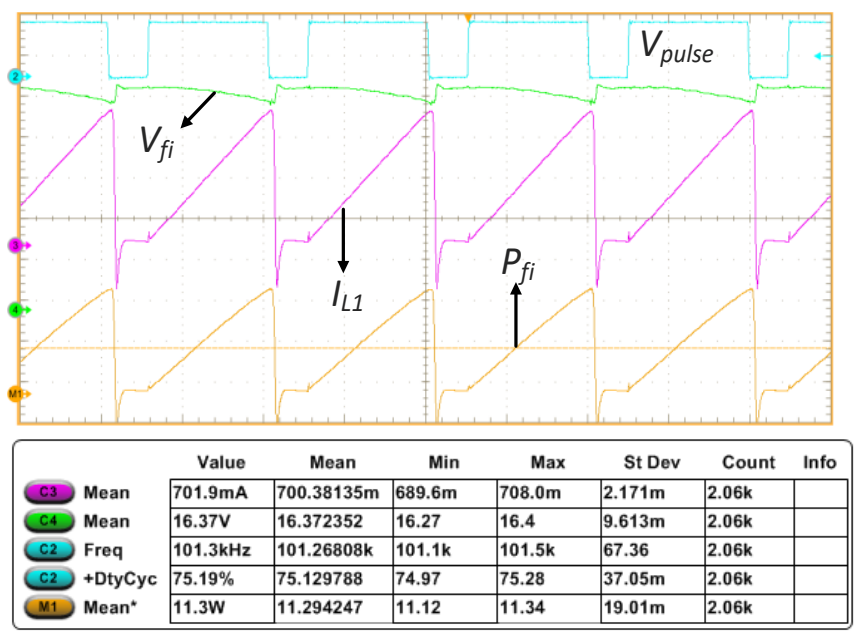

Figure 18. Flyback input power graph.

Table 5. Percentage error.

\begin{tabular}{cccc}
\hline Parameter & Ideal-PSpice & PSpice-Prototype & Ideal-Prototype \\
\hline Input Voltage $V_{\text {in }}$ & $0.0 \%$ & $0.0 \%$ & $0.0 \%$ \\
Internal resistance $R s$ & $0.0 \%$ & $0.0 \%$ & $0.0 \%$ \\
Input current $I_{\text {in }}$ & $5.1 \%$ & $7.5 \%$ & $2.8 \%$ \\
Input power $P_{\text {in }}$ & $5.1 \%$ & $7.5 \%$ & $2.8 \%$ \\
Power consumed in $R_{s}$ & $12.1 \%$ & $16.7 \%$ & $6.6 \%$ \\
Primary inductor $L_{1}$ & $0.0 \%$ & $13.0 \%$ & $13.0 \%$ \\
Secondary inductor $L_{2}$ & $0.0 \%$ & $10.8 \%$ & $10.8 \%$ \\
Flyback input power $P_{f i}$ & $13.6 \%$ & $5.4 \%$ & $7.5 \%$ \\
Flyback output power $P_{f o}$ & $13.4 \%$ & $6.1 \%$ & $6.5 \%$ \\
Load $R_{o}$ & $0.0 \%$ & $7.4 \%$ & $7.4 \%$ \\
Output voltage $V_{o}$ & $0.0 \%$ & $0.6 \%$ & $0.7 \%$ \\
Output current $I_{o}$ & $0.0 \%$ & $4.3 \%$ & $4.3 \%$ \\
Output power $P_{o}$ & $0.1 \%$ & $3.8 \%$ & $3.7 \%$ \\
Processed power in flyback $Q$ & $10.9 \%$ & $1.7 \%$ & $9.0 \%$ \\
Flyback efficiency $\eta_{f}$ & $0.2 \%$ & $0.7 \%$ & $0.9 \%$ \\
Real system efficiency $\eta_{s}$ & $2.3 \%$ & $0.0 \%$ & $2.3 \%$ \\
\hline
\end{tabular}

In Figure 19, the output voltage of the flyback converter $\left(V_{f_{0}}\right)$ is $14.76 \mathrm{~V}$ at $4 \mathrm{~V} / \mathrm{div}$, the average current through the secondary side $\left(I_{L 2}\right)$ is $681.1 \mathrm{~mA}$ at $2 \mathrm{~A} / \mathrm{div}$, the maximum peak current is $6.6 \mathrm{~A}$, and the $\left(P_{f_{0}}\right)$ flyback average output power is $10.08 \mathrm{~W}$ at $25 \mathrm{~W} /$ div.

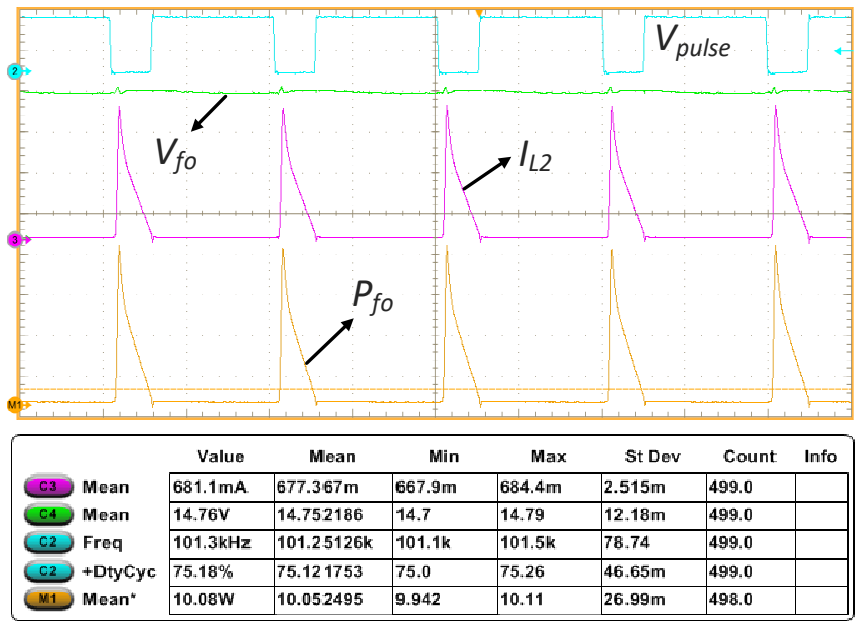

Figure 19. Flyback output power graph. 
There are different references that present similar results to this work. For example, reference [30] presents an efficiency of $92.6 \%$ for an input power of $30 \mathrm{~W}$ using a Buck-Boost converter with an open-circuit voltage measurement technique. Reference [15] shows an efficiency of $88.7 \%$ for an input power of $30 \mathrm{~W}$ using a Boost converter with Incremental Conductance technique. Reference [16] presents an efficiency of $90.126 \%$ for an input power of $24.04 \mathrm{~W}$ using a flyback converter with Incremental Conductance technique. This paper shows an efficiency of $92.65 \%$ for an input power of $20.054 \mathrm{~W}$ using the proposed flyback converter with a constant duty cycle of $75 \%$. Efficiency is expected to improve when using an MPPT control technique.

\section{Conclusions}

This work presents a theoretical analysis of a converter which is based on a variant of the flyback converter and is used for energy harvesting applications based on thermoelectric generators, providing advantages such as partial power processing and less voltage and current stress in the converter.

A prototype was built that delivered $18 \mathrm{~W}$ at a resistive load and had an efficiency of $92.65 \%$. The main advantage of this converter was verified, which is the partial power processing, since $56.34 \%(11.3 \mathrm{~W})$ of the energy was processed by the flyback converter while $43.66 \%(8.7 \mathrm{~W})$ of the energy is delivered directly to load. Since in this rearrangement the flyback converter processes less energy, it was obtained that the voltage in the components is lower than in a conventional flyback. The output voltage of the flyback converter $\left(V_{f_{0}}\right)$ was $14.959 \mathrm{~V}$, which is just a part of the output voltage $\left(V_{o}\right)$ which is $30.5 \mathrm{~V}$. Furthermore, this operation allows the efficiency of the proposed converter to always be higher than that of the conventional flyback converter. If only the efficiency of the flyback converter is considered $\left(\eta_{f}\right)$, this is $89.2 \%$. However, the efficiency of the complete system $\left(\eta_{s}\right)$ thanks to the rearrangement of the elements is $92.65 \%$. The main disadvantages of the converter are that it has no magnetic isolation and that it is only a boost topology.

For future works, the efficiency of the system is expected to be increased by using a Maximum Power Point Tracking control technique for the proposed convert.

Author Contributions: Conceptualization R.M.-A., D.S.-P., M.P.-S. and H.H.-D.L.; data curation, R.M.-A., D.S.-P. and J.A.A.-T.; formal analysis, D.S.-P., M.P.-S., R.M.-A. and J.L.; funding acquisition, M.P.-S., Y.I.S.-B. and E.N.E.-G.; investigation, R.M.-A., M.P.-S. and R.E.L.-P.; methodology, M.P.-S., R.M.-G. and R.E.L.-P.; project administration, R.E.L.-P., Y.I.S.-B.; resources, R.M.-G., M.P.-S., H.H.-D.L. and E.N.E.-G. software, Y.I.S.-B., J.A.A.-T. and J.L.; supervision, M.P.-S., H.H.-D.L. and J.L.; validation, D.S.-P., M.P.-S. and H.H.-D.L.; visualization, D.S.-P., M.P.-S., Y.I.S.-B. and J.L.; writing-original draft, D.S.-P., M.P.-S. and R.M.-A.; writing—review \& editing, R.E.L.-P., H.H.-D.L., Y.I.S.-B. and E.N.E.-G. All authors have read and agreed to the published version of the manuscript.

Funding: This research was funded by Tecnologico Nacional de Mexico.

Conflicts of Interest: The authors declare no conflict of interest.

\section{References}

1. Lv, S.; He, W.; Jiang, Q.; Hu, Z.; Liu, X.; Chen, H.; Liu, M. Study of different heat exchange technologies influence on the performance of thermoelectric generators. Energy Convers. Manag. 2018, 156, 167-177. [CrossRef]

2. Sudharshan, K.; Kumar, V.P.; Barshilia, H.C. Performance evaluation of a thermally concentrated solar thermo-electric generator without optical concentration. Sol. Energy Mater. Sol. Cells 2016, 157, 93-100. [CrossRef]

3. Maran, A.L.O.; Henao, N.C.; Silva, E.A.; Schaeffer, L.; Junior, O.H.A. Use of the Seebeck Effect for Energy Harvesting. IEEE Lat. Am. Trans. 2016, 14, 4106-4114. [CrossRef]

4. Datas, A.; Martí, A. Thermophotovoltaic energy in space applications: Review and future potential. Sol. Energy Mater. Sol. Cells 2017, 161, 285-296. [CrossRef]

5. Cao, Q.; Luan, W.; Wang, T. Performance enhancement of heat pipes assisted thermoelectric generator for automobile exhaust heat recovery. Appl. Therm. Eng. 2018, 130, 1472-1479. [CrossRef]

6. Kumar, T.K.; Kumar, S.A.; Ram, K.K.; Goli, K.R.; Prasad, V.S. Analysis of thermo electric generators in automobile applications. Mater. Today Proc. 2020. [CrossRef] 
7. Sornek, K.; Filipowicz, M.; Żołądek, M.; Kot, R.; Mikrut, M. Comparative analysis of selected thermoelectric generators operating with wood-fired stove. Energy 2019, 166, 1303-1313. [CrossRef]

8. Dalala, Z.M.; Hamdan, Z.S.; Al-Taani, H.; Al-Addous, M.; Albatayneh, A. Battery Charging Application with Thermoelectric Generators as Energy Harvesters. Acad. Res. Community Publ. 2019, 3, 248. [CrossRef]

9. Ebling, D.G.; Krumm, A.; Pfeiffelmann, B.; Gottschald, J.; Bruchmann, J.; Benim, A.C.; Ádám, M.; Labs, R.; Herbertz, R.R.; Stunz, A. Development of a System for Thermoelectric Heat Recovery from Stationary Industrial Processes. J. Electron. Mater. 2016, 45, 3433-3439. [CrossRef]

10. Francioso, L.; De Pascali, C.; Sglavo, V.; Grazioli, A.; Masieri, M.; Siciliano, P. Modelling, fabrication and experimental testing of an heat sink free wearable thermoelectric generator. Energy Convers. Manag. 2017, 145, 204-213. [CrossRef]

11. Ma, Q.; Fang, H.; Zhang, M. Theoretical analysis and design optimization of thermoelectric generator. Appl. Therm. Eng. 2017, 127, 758-764. [CrossRef]

12. Yu, H.; Chen, M.; Wu, C.; Tang, K.-T.; Wang, G. A batteryless and single-inductor DC-DC boost converter for thermoelectric energy harvesting application with 190mV cold-start voltage. In Proceedings of the 2018 IEEE International Symposium on Circuits and Systems (ISCAS), Florence, Italy, 27-30 May 2018; pp. 1-4.

13. Moreno, J.M.; Vazquez, A.S.M.; Barragan, C.A.B.; Gonzalez, J.M.V.; Rosas, J.C.A. Radio Frequency Energy Harvesting System Making Use of $180^{\circ}$ Hybrid Couplers and Multiple Antennas to Improve the DC Output Voltage. IEEE Lat. Am. Trans. 2020, 18, 604-612. [CrossRef]

14. Chen, I.-C.; Liang, C.-W.; Tsai, T.-H. A Single-Inductor Dual-Input Dual-Output DC-DC Converter for Photovoltaic and Piezoelectric Energy Harvesting Systems. IEEE Trans. Circuits Syst. II Express Briefs 2019, 66, 1763-1767. [CrossRef]

15. Twaha, S.; Zhu, J.; Yan, Y.; Li, B.; Huang, K. Performance analysis of thermoelectric generator using dc-dc converter with incremental conductance based maximum power point tracking. Energy Sustain. Dev. 2017, 37, 86-98. [CrossRef]

16. Bhattacharya, A.; Majumdar, S. Design of a 22 W (0.7 A) Current Controlled DC-DC Flyback Converter Operating in DCM Mode. In Emerging Trends in Electrical, Communications, and Information Technologies; Springer: New York, NY, USA, 2020 ; pp. $247-258$.

17. CPesce, C.; Riedemann, J.; Pena, R.; Jara, W.; Maury, C.; Villalobos, R. A Modified Step-Up DC-DC Flyback Converter with Active Snubber for Improved Efficiency. Energies 2019, 12, 2066.

18. Boeke, U. High efficiency flyback converter technology. In Proceedings of the 2007 Power Conversion Conference-Nagoya, Nagoya, Japan, 2-5 April 2007; pp. 1268-1273.

19. Eshkevari, A.L.; Mosallanejad, A.; Sepasian, M.S. Design, modelling, and implementation of a modified double-switch flybackforward converter for low power applications. IET Power Electron. 2019, 12, 739-748. [CrossRef]

20. Fathabadi, H. Novel solar-powered photovoltaic/thermoelectric hybrid power source. Renew. Energy 2020, 146, 426-434. [CrossRef]

21. Giang, V.T.; Vinh, V.T. Highly Efficient step-up Boost-Flyback coupled magnetic integrated converter for photovoltaic energy. Int. J. Circuits Electron. 2018, 3, 14-18.

22. Somiruwan, G.; Gunawardena, L.; Nayanasiri, D.; Li, Y. High-Step-Up Boost Converter Based on Coupled Inductor, Voltage Lift and Clamp Cells. In Proceedings of the 2019 IEEE Applied Power Electronics Conference and Exposition (APEC), Anaheim, CA, USA, 17-21 March 2019; pp. 2305-2310.

23. Camponogara, D.; Ferreira, G.F.; Campos, A.; Costa, M.A.D.; Garcia, J. Offline LED driver for street lighting with an optimized cascade structure. IEEE Trans. Ind. Appl. 2013, 49, 2437-2443. [CrossRef]

24. Tse, C.K.; Chow, M.H.L.; Cheung, M.K.H. A family of PFC voltage regulator configurations with reduced redundant power processing. IEEE Trans. Power Electron. 2001, 16, 794-802. [CrossRef]

25. Morales-Saldaña, J.A.; Loera-Palomo, R.; Palacioshernandez, E.R.; González-Martínez, J.L. Modelling and control of a DC-DC quadratic boost converter with R 2 P 2. IET Power Electron. 2014, 7, 11-22. [CrossRef]

26. Zogogianni, C.G.; Tatakis, E.C.; Vekic, M.S. Non-Isolated Reduced Redundant Power Processing DC/DC Converters: A Systematic Study of Topologies With Wide Voltage Ratio for High-Power Applications. IEEE Trans. Power Electron. 2019, 34, 8491-8502. [CrossRef]

27. Zogogianni, C.G.; Tatakis, E.C.; Porobic, V. Investigation of a Non-isolated Reduced Redundant Power Processing DC/DC Converter for High-Power High Step-Up Applications. IEEE Trans. Power Electron. 2018, 34, 5229-5242. [CrossRef]

28. Ponce-Silva, M.; Salazar-Pérez, D.; Rodríguez-Benítez, O.M.; Vela-Valdés, L.G.; Claudio-Sánchez, A.; De León-Aldaco, S.E.; CortésGarcía, C.; Saavedra-Benítez, Y.I.; Lozoya-Ponce, R.E.; Aquí-Tapia, J.A. Flyback Converter for Solid-State Lighting Applications with Partial Energy Processing. Electronics 2020, 10, 60. [CrossRef]

29. Zapata, J.W.; Kouro, S.; Carrasco, G.; Renaudineau, H. Step-Up Partial Power DC-DC Converters for Two-Stage PV Systems with Interleaved Current Performance. Energies 2018, 11, 357. [CrossRef]

30. Montecucco, A.; Knox, A.R. Maximum Power Point Tracking Converter Based on the Open-Circuit Voltage Method for Thermoelectric Generators. IEEE Trans. Power Electron. 2014, 30, 828-839. [CrossRef] 